\title{
Deiksis pada Wacana Sastra Cerpen Bermuatan Kearifan Lokal Mahasiswa Program Studi Pendidikan Bahasa Indonesia
}

\author{
Lailiyatus Sa'diyah \\ Universitas Nahdlatul Ulama Blitar, Indonesia \\ Email: Lailiyatus_Sadiyah@yahoo.com
}

\begin{tabular}{l} 
Tersedia Online di \\
\hline http://www.jurnal.unublitar.ac.id/ind \\
ex.php/briliant \\
\hline Sejarah Artikel \\
\hline Diterima pada 3 November 2019 \\
Disetujui pada 12 November 2019 \\
Dipublikasikan pada 30 November \\
2019 Hal. 464-472 \\
\hline Kata Kunci: \\
\hline Deiksis, Cerpen, Kearifan Local \\
DOI: \\
http://dx.doi.org/10.28926/briliant.v3 \\
i4.402
\end{tabular}

\begin{abstract}
Abstrak: Penelitian ini meneliti penggunaan deiksis pada cerpen tulisan mahasiswa program studi pendidikan Bahasa Indonesia semester tiga tahun akademik 2018/2019 yang selama ini belum pernah diketahui bentuk, jenis, dan makna bentuknya. Selain itu, didasarkan pada pentingnya fungsi-fungsi deiksis yang dimilikinya dalam penggunaan bahasa. Data penelitian ini berupa kata atau konstruksi sintaksis (frase atau lebih dari frase) yang menandai adanya tindak pengacuan terhadap sesuatu dengan unsur bahasa tertentu (deictic expression) yang memiliki fungsi penting diantaranya memunculkan acuan yang dimaksud oleh penutur ke dalam tuturannya. Mengkhususkan acuan tertentu dari sejumlah kemungkinan acuan, penggunaan deiksis serta perwujudan ekspresi deiksis dalam setip jenis yang dimunculkan.
\end{abstract}

\section{PENDAHULUAN}

Deiksis sebagai salah satu kajian pragmatik merupakan gejala semantis pada kata atau kontruksi kata yang hanya dapat diketahui acuannya dengan memperhitungkan situasi pembicaraan. Kata bisa dikatakan bersifat deiksis jika referennya berpindah-pindah, misalnya kata sekarang dapat diketahui rujukannya jika diketahui siapa, pada siapa pada waktu apa dan tempat dituturkannya kata itu.

Deiksis menurut Kridalaksana (2008:45) fungsi yang menunjuk sesuatu di luar bahasa yang mempunyai fungsi deiksis. Menurut Verhaar (1998:320) deiksis adalah semantik(di dalam tuturan tertentu) yang berasal pada identitas penutur. Semantik bisa bersifat gramatikal dan bisa bersifat leksikal serta acuannya merupakan akar referensi dan perlu diketahui identitasnya. Senada dengan pendapat tersebut, Cahyono (1995:217) menyatakan deiksis adalah cara untuk mengacu hakekat tertentu dengan bahasa yang hanya dapat ditafsirkan berdasarkan makna yang diacu oleh penutur dan dipengaruhi oleh situasi pembicaraan. Deiksis bisa diartikan sebagai lokasi, identifikasi orang, objek, peristiwa, kegiatan yang sedang dibicarakan atau yang diacu dalam hubungannya dengan dimensi ruang dan waktu, pada saat dituturkan oleh pembicara atau yang diajak bicara (Lyons, 1977:637). Berdasarkan dari berbagai pendapat di atas, dapat disimpulkan bahwa deiksis adalah kata atau kontruksi kata yang memiliki referen atau acuan yang berubah-ubah atau berganti-ganti bergantung pada saat 
pembicara mengutarakan ujaran tersebut dan dipengaruhi oleh konteks atau situasi yang terjadi saat tuturan berlangsung.

Linguistik memiliki istilah rujukan atau disebut referensi, yaitu kata atau frase yang menunjuk ungkapan yang akan diberikan. Ungkapan semacam itu disebut deiksis (Nababan (1987:40). Kata dikatakan deiksis apabila rujukaannya berpindah-pindah bergantung pada siapa pembicaranya atau bergantung pada saat dan tempat dituturkannya kata itu (Purwo, 1984:1). Senada dengan pendapat tersebut Wijana (1998:6) berpendapat bahwa kata yang memiliki rujukan berubah-ubah atau berpindah-pindah disebut deiksis. Berdasarkan dari berbagai pendapat di atas, deiksis adalah kata yang referennya berpindah-pindah bergantung siapa dan tempat diungkapkannya.

Wacana memiliki makna terbatas dan luas. Wacana memiliki makna terbatas apabila menunjuk pada aturan dan kebiasaan yang mendasari penggunaan bahasa lisan maupun tulisan. Wacana juga disebut dengan teks. Beberapa ahli menggunakan istilah teks untuk merujuk pada wacana. Menurut Widdowson (2004:3) wacana adalah kalimat tertulis dalam jumlah yang besar. Berdasarkan dari berbagai pendapat di atas, wacana dan kalimat memiliki objek kajian yang sama karena tidak ada perbedaan konseptual diantara keduanya.

Secara lebih luas Johnstone (2008:2) berpendapat bahwa wacana adalah bentuk komunikasi nyata yang menggunakan bahasa sebagai medianya. Hal ini sejalan dengan pendapat Gee (2005:21) wacana adalah cara mengombinasikan dan mengintegrasikan bahasa, tindakan, interaksi, simbol, alat, dan objek untuk memerankan sebuah identitas sosial yang dapat dikenali pada karya fiksi berupa cerpen dan karya fiksi lainnya. Unsur pragmatic cerpen maupun karya fiksi lainnya dapat dianalisis melalui pragmatik. Hal ini dapat mencakup berbagai factor dan juga tindakan bahasa atau deiksi seperti dilakukan dalam penelitian ini.

Tujuan khusus penelitian ini memilih penggunaan deiksis pada wacana sastra berupa cerpen tulisan mahasiswa program studi pendidikan bahasa Indonesia semester tiga UNU Blitar tahun akademik 2018/2019 yang selama ini belum pernah diketahui bentuk, jenis, dan makna bentuknya. Selain itu, didasarkan juga pada pentingnya fungsi-fungsi deiksis yang dimilikinya dalam penggunaan bahasa. Selain itu hasil penelitian ini diharapkan dapat memberikan manfaat baik secara teoritis maupun secara praktis bagi mahasiswa. Secara teoritis, bagi pengembangan ilmu bahasa yang ada.

\section{METODE}

Penelitian ini menggunakan pendekatan kualitatif yaitu mendeskripsikan deiksis (bentuk, jenis, dan makna bentuk) berupa kata dan kontruksi sintaksis (frase atau lebih dari frase) wacana sastra cerpen mahasiswa program studi pendidikan bahasa Indonesia semester tiga UNU Blitar tahun akademik 2018/2019. Pada kepentingan tersebut, peneliti berkedudukan sebagai human instrumen yaitu membaca berulang dan mendalam terhadap sumber data wacana sastra cerpen mahasiswa program studi pendidikan bahasa Indonesia semester tiga UNU Blitar tahun akademik 2018/2019. Dengan tindakan tersebut, diperoleh data berupa kata atau konstruksi sintaksis (frase atau lebih dari frase) yang menandai adanya fungsi deiktis dalam wacana sastra cerpen mahasiswa program studi pendidikan bahasa Indonesia semester tiga UNU Blitar tahun akademik 2018/2019. Data tersebut dianalisis dengan prosedur alir (Flow model analysis). 


\section{HASIL DAN PEMBAHASAN}

Permasalahan penelitian diuraikan menjadi lima; (1) deiksis persona, (2) deiksis tempat, (3) deiksis waktu, (4) deiksis wacana, dan (5) deiksis sosial. Lebih jelas temuan penelitian disajikan pada uraian berikut:

\section{Deiksis Persona}

Menurut Purwo (1991:178) jenis deiksis ada lima, yaitu deiksis persona atau orang, deiksis tempat, deiksis waktu, deiksis wacana dan deiksis social. Deiksis persona merupakan pemberian bentuk personal tiga kelas kata ganti diri yaitu; satu orang pertama, kedua orang kedua, dan ketiga orang ketiga. Mengacu pada hal tersebut, orang pertama merujuk pada dirinya sendiri, misalnya saya, $a k u$, kami dan kita. Orang kedua merujuk pada seseorang atau siapa saja yang dituju dalam pembicaraan, misalanya kamu, engkau, Anda, kalian, saudara. Sedangkan, orang ketiga merujuk pada orang yang bukan pembicara dan bukan pula pendengar. Misalnya ia, dia, ia, beliau, mereka.

Pronomina persona yaitu (a) pronominal pertama tunggal bentuknya yaitu $a k u$, saya, daku. Sedangkan pronomina persona kedua tunggal yaitu kamu, dan Anda, saudara, engkau. Leksem kekerabatan misalnya bapak, ibu, kakak dan leksem jabatan seperti guru, dokter, kyai. Pronominal persona ketiga yaitu bentuk tunggal dan bentuk jamak. Bentuk tunggal pronominal persona ketiga mempunyai dua bentuk yaitu, ia dan dia yang mempunyai variasinya. Bentuk pronominal persona ketiga jamak adalah beliau, mereka.

Pembahasan dalam penelitian ini yaitu mencakup deiksis persona, deiksis tempat, deiksis waktu, deiksis wacana, dan deiksis sosial wacana sastra cerpen mahasiswa program studi pendidikan bahasa Indonesia semester tiga UNU Blitar tahun akademik 2018/2019. Pembahasan temuan penelitian disajikan berikut ini.

\section{Deiksis Persona wacana sastra cerpen mahasiswa program studi pendidikan Bahasa Indonesia semester tiga UNU Blitar tahun akademik 2018/2019}

Deiksis persona pertama tunggal memiliki bentuk aku, saya, dan daku. Bentuk deiksis persona kedua tunggal adalah kamu dan engkau. Sedangkan deiksis persona ketiga memiliki bentuk tunggal dan jamak. Bentuk tunggal deiksis persona ketiga memiliki dua bentuk yaitu, ia dan dia. Sedangkan bentuk persona ketiga jamak adalah beliau, mereka.

\section{Leksem Persona Pertama}

Kata $a k u$, saya dan daku yang merujuk pada si pembicara itu sendiri atau dirinya sendiri ditemukan dalam cerpen ditandai pada kutipan cerpen berikut:

Sebelum berangkat sekolah aku selalu menjajakan tempe ke rumah-rumah tetangga. Di tempat-tempat tertentu $a k u$ berhenti agak lama melayani pembeli. Di sinilah $a k u$ biasa menumpang gosip. $\boldsymbol{A S 4}$

Leksem persona pertama $a k u$ yang ditemukan dalam data karangan cerpen tulisan mahasiswa prodi pendidikan Bahasa Indonesia merupakan jenis deiksis leksem persona pertama tunggal. Leksem persona pertama tunggal aku merujuk pada jangkauan pembicara atau dirinya sendiri. 


\section{Leksem Persona Kedua}

Kalimat yang mengandung deiksis persona kedua tunggal yaitu kamu, dan Anda, saudara, engkau. Dan juga bentuk kekerabatan seperti bapak, ibu, kakak dan leksem jabatan seperti guru, dokter, kyai. Ditemukan dalam cerpen ditandai pada kutipan cerpen berikut:

Perkenalkan namaku Dinar. Nama kamu siapa? GFF64

Leksem persona kedua kamu yang ditemukan dalam data karangan cerpen tulisan mahasiswa prodi pendidikan Bahasa Indonesia merupakan jenis deiksis leksem persona kedua tunggal. Leksem persona kedua tunggal kamu mengacu pada jangkauan seseorang atau lebih dari pendengar atau siapa saja yang dituju dalam pembicaraan.

\section{Leksem Persona Ketiga}

Kalimat yang mengandung pronomina persona ketiga mengacu pada orang yang bukan pembicara dan bukan pula pendengar seperti ia, dia, ia, beliau, mereka ditemukan dalam cerpen ditandai pada kutipan cerpen berikut:

Waktu ia menabung, tidak tau tiba-tiba uang yang ia tabung malah hilang separuhnya. Ia pun merasa sangat sedih. Akan tetapi ia tidak putus asa. ECN26

Leksem persona ketiga ia yang ditemukan dalam data karangan cerpen tulisan mahasiswa prodi pendidikan bahasa Indonesia merupakan jenis deiksis leksem persona ketiga . Leksem persona ketiga ia mengacu pada jangkauan bukan pembicara dan bukan pula pendengar.

\section{Deiksis Tempat}

Deiksis tempat merupakan bentuk lokasi penutur dalam peristiwa bahasa. Deiksis tempat dipandang dari hubungan orang dan benda yang ditunjuk dibagi menjadi dua; pertama, jauh (distal) dan dekat (proksimal) seperti di sana, itu dan sebagainya. Dimungkinkan juga dasar deiksis tempat adalah jarak psikologis. Kedekatan objek secara fisik dipergunakan penutur sebagai kedekatan psikologis. Sedangkan sesuatu yang jauh secara fisik juga diperlakukan jauh berdasarkan pendekatan psikologis seperti kata itu.

\section{Leksem Tempat}

Kalimat yang mengandung leksem tempat dekat (proksimal) seperti $d i$ sana, itu dan sebagainya. Ditemukan dalam cerpen ditandai pada kutipan cerpen berikut:

Disana lah bintang Sirius. Ya, aku menyebutnya begitu. Berkelipkelip oleh perubahan suhu atmosfer. $\boldsymbol{A S} \boldsymbol{4}$

Leksem tempat di sana yang ditemukan dalam karangan cerpen tulisan mahasiswa prodi pendidikan bahasa Indonesia merupakan jenis deiksis leksem tempat. Leksem tempat disana merujuk leksem tempat dekat (proksimal).

\section{Deiksis Waktu}


Deiksis waktu dapat dilihat dari aspek jenis deiksis waktu lampau atau waktu dulu, waktu kini, dan waktu akan datang. Dari paparan data secara keseluruhan, terdapat jenis deiksis waktu yang bermacam-macam, meliputi: (1) waktu lampau (2) waktu kini dan (3) waktu akan datang. Jenis deiksis waktu lampau dulu, saat, ketika, kemarin, lalu, sebelum, tadi. Deiksis waktu kini menggunakan leksem waktu kini, saatnya, pada, di. Dan deiksis waktu akan datang menggunakan leksem waktu kemudian, lalu, sore harinya, keesokan harinya.

Deiksis waktu dapat dilihat dari aspek makna bentuk deiksis waktu berupa satuan kalender, rotasi bumi, dan satuan jam. Dari paparan data secara keseluruhan, terdapat makna bentuk deiksis waktu yang bermacam-macam, meliputi: (1) satuan kalender (2) rotasi bumidan (3) satuan jam.

\section{Leksem waktu kini dan Leksem sekarang}

Kata kini mirip dengan kata sekarang karena keduanya bertitik labuh pada saat tuturan. Akan tetapi keduanya memiliki perbedaan (Purwo, 1984:210). Perbedaannya dapat dilihat pada analisis di bawah ini.

\section{Waktu terus berlalu, $\boldsymbol{k i n i}$ aku sudah menjadi mahasiswa.. LK17}

Leksem "kini" pada kutipan karangan cerpen di atas merupakan bentuk deikisis waktu berupa kata tunggal dan termasuk morfem bebas yang bersifat terbuka terhadap afiksasi. Leksem waktu "kini" pada data digunakan sebagai kata ganti keterangan waktu dan memiliki distribusi terbatas dalam kalimat. Kata kini berdistribusi terbatas karena klausa yang membawakan waktu lampau harus disebutkan mendahului penyebutan klausa yang dihadiri kata kini.

Sekarang aku merayakan pergantian tahun sendiri. Aku merasa sangat sedih.NWT24

Leksem waktu sekarang yang ditemukan dalam data karangan cerpen tulisan di atas merupakan jenis deiksis waktu kini. Leksem waktu sekarang merujuk pada jangkauan waktu kini telah sedang berlangsung dalam tuturan (kalimat). Tanpa dikaitkan dengan waktu lampau kata sekarang bisa berdiri sendiri sebagai kata ganti keterangan waktu.

Perbedaan kedua kata tersebut dikupas lebih lanjut pada pembahasan di bawah ini. Kata kini dan kata sekarang keduanya sama-sama memiliki arti bertitik labuh pada saat tuturan. Meskipun kata kini dan sekarang sama-sama bertitik labuh pada saat tuturan, keduanya tampak memiliki perbedaan.

(1) Karena dulu kau pernah menipu $\{$ kini $\}$ tak ada orang yang percaya lagi padamu $\{$ sekarang $\}$

(2) $\{$ *kini $\}$ tak ada lagi orang yang percaya lagi kepadamu karena dulu kau \{sekarang $\}$ pernah menipu.

kalimat (1) kata kini dan sekarang keduanya dapat berada dalam klausa kedua, tetapi apabila urutan klausa itu dibalik maka hanya kata sekarang yang dapat berada pada klausa pertama kalimat (2). Kata kini mengandaikan adanya kesinambungan antara waktu lampau dengan saat tuturan; oleh karena itu klausa 
yang membawakan waktu lampau harus disebutkan mendahului penyebutan klausa yang dihadiri kata kini.

Tanpa dikaitkan dengan waktu lampau kata kini tidak dapat berdiri sendiri menunjuk saat tuturan dan kata kini memiliki distribusi terbatas dibandingkan dengan kata sekarang, misalnya juga pada kalimat di bawah ini.

Bisa $\left\{\begin{array}{l}* \text { kini? } \\ \text { sekarang? }\end{array}\right\}$

Kata kini dapat berkorelasi dengan waktu lampau apabila ditunjukkan dengan kata dulu sebagai kata ganti keterangan waktu sebelum kata kini dalam kalimat. Misalnya pada contoh di bawah ini.

Karena dulu kau pernah menipu,
padamu. $\left\{\begin{array}{l}\text { kini } \\ \text { sekarang }\end{array}\right\}$ tak ada orang yang percaya lagi

Berdasarkan analisis data di atas, diketahui bahwa karangan cerpen mahasiswa prodi pendidikan bahasa Indonesia dalam menggunakan deiksis waktu penunjuk kata ganti keterangan waktu, menggunakan kata kini dan sekarang untuk menunjukkan waktu yang bertitik labuh pada saat tuturan (kalimat). Tanpa dikaitkan dengan waktu lampau kata kini tidak dapat berdiri sendiri menunjuk saat tuturan dan kata kini memiliki distribusi terbatas dibandingkan dengan kata sekarang. Kata kini dan sekarang merupakan bentuk deiksis waktu kategori tunggal dan termasuk jenis deiksis waktu kini.

\section{Leksem Waktu pagi-pagi}

Bentuk pengulangan atau reduplikasi dari leksem waktu yang berporos pada posisi bumi terhadap matahari memiliki arti men-dini-kan atau meng-awalkan misalnya kata pagi-pagi pada kutipan karangan narasi di bawah ini.

Pagi-pagi aku terpaksa harus bangun, karena harus segera berangkat kuliah. MP26

Pagi-pagi merupakan Bentuk reduplikasi dari leksem waktu pagi. Pagipagi dalam kalimat mengacu posisi bumi terhadap matahari memiliki arti 'mengawal-kan' atau 'men-dini-kan'. Pagi-pagi yang dimaksudkan dalam kalimat adalah 'sangat pagi' atau 'terlalu pagi'

$$
\left\{\begin{array}{l}
\text { pagi-pagi } \\
\text { malam-malam } \\
\text { siang-siang } \\
\text { sore-sore }
\end{array}\right\}
$$

Bentuk pengulangan atau reduplikasi leksem waktu yang mengacu pada posisi bumi terhadap matahari dapat pula berarti 'men-terlambat-kan' seperti pada kata malam-malam di bawah ini.

Tina tidak boleh tidur malam-malam, kawatir bangun terlambat.

Sebetulnya ada persamaan diantara keduanya karena yang dimaksudkan dengan pagi-pagi adalah 'sangat pagi' atau 'terlalu pagi', dan malam-malam adalah 'terlalu malam'. Pengertian awal atau lambat ini menunjukkan bahwa pagi 
sebagai mulainya hari, sedangkan malam sebagai akhirnya hari.Pengertian awal dan terlambat ini tidak dapat diterapkan pada bentuk reduplikasi kata siang dan kata sore karena kedua kata ini bukan merupakan batas perubahan hari.

Berdasarkan analisis data di atas, diketahui bahwa cerpen mahasiswa prodi pendidikan bahasa Indonesia dalam menggunakan deiksis waktu penunjuk kata ganti keterangan waktu, menggunakan deiksis waktu bentuk pengulan gan atau reduplikasi pagi-pagi. Reduplikasi pagi-pagi merupakan bentuk reduplikasi dari leksem waktu pagi yang berpatokan pada posisi bumi terhadap matahari.

\section{Deiksis Wacana}

Deiksis wacana berdasarkan antesedennya dibagi menjadi anaphora dan katafora. Anaphora adalah deiksi yang mengacu yang dekat seperti ini, itu, yang terdahulu. Sedangkan katafora deiksis yang mengacu pada yang jauh atau apa yang telah disebut seperti yang berikut, di bawah ini, sebagai berikut.

\section{Leksem Wacana Anafora}

Kalimat yang mengandung Anaphora adalah deiksis yang mengacu yang akan disebut seperti ini, itu, yang terdahulu. Ditemukan dalam cerpen ditandai pada kutipan cerpen berikut:

Terus gimana Pak? Ini sudah sore. Nanti kalau kesorean tidak dapat janur. QMF134

Leksem wacana anaphora ini yang ditemukan dalam data karangan cerpen tulisan mahasiswa prodi pendidikan Bahasa Indonesia merupakan jenis deiksis deiksis yang mengacu yang akan disebut.

\section{Deiksis Sosial}

Deiksis sosial menunjukkan kesopanan berbahasa. Deiksis sosial mengacu ciri sosial antara pembcara dan lawan bicara atau penulis dan pembaca dengan topik atau rujukan yang dimaksud dalam pembicaraan. Deiksis social ditunjukkan melalui sistem honorofiks (sopan santun berbahasa) seperti pronomina persona (sampean, panjenengan, piyambakipun) serta sistem sapaan dan penggunaan gelar. Selain itu eufimisme (pemakaian kata halus) penggantian kata gelandangan dengan tunawisma. Kata mati diganti dengan meninggal, wafat, dan mangkat.

\section{Leksem Sosial}

Kalimat yang mengandung leksem sosial adalah deiksis yang menunjukkan adanya kesopanan berbahasa. Deiksis sosial mengacu sistem honorofiks (sopan santun berbahasa atau kesantunan berbahasa) seperti deiksis persona (sampean, panjenengan, piyambakipun) serta penggunaan sistem sapaan dan penggunaan gelar. Ditemukan dalam cerpen ditandai pada kutipan cerpen berikut:

Untuk pembacaan mantra ataupun doa, saya serahkan kepada bapak ibu sekalian, saya ikut panjenengan semua. $\boldsymbol{D Z 2 2}$

Leksem social panjenengan yang ditemukan dalam data karangan cerpen tulisan mahasiswa prodi pendidikan Bahasa Indonesia merupakan jenis deiksis deiksis yang menunjukkan adanya kesopanan berbahasa. 


\section{KESIMPULAN}

Berdasarkan hasil dan pembahasan, dapat disimpulkan deiksis diartikan identifikasi orang, objek, peristiwa, proses atau kegiatan yang sedang dibicarakan atau yang sedang diacu dalam hubungannya dengan dimensi ruang dan waktu, pada saat dituturkan oleh penutur kepada mitra tutur. Berdasarkan pembagiannya, deiksis dibagi menjadi lima jenis yaiu deiksis persona, deiksis tempat, deiksis waktu, deiksis wacana, dan deiksis sosial.

Deiksis persona atau orang adalah bentuk personal atau orang, yang mencangkup tiga kelas kata ganti diri, yaitu: orang pertama (saya, aku, kami, dan kita), orang kedua (kamu, engkau, Anda, kalian, saudara), dan orang ketiga (dia, ia, beliau, mereka). Deiksis tempat merupakan merupakan tempat, dipandang dari lokasi pemeran dalam persitiwa berbahasa (di sini, di situ, di sana). Deiksis waktu merupakan pemberian bentuk kepada titik atau jarak dipandang dari waktu uangkapan itu dibuat (kini, kemarin, lusa, sekarang, besok, dulu, tadi, nanti. Deiksis wacana berdasarkan antesedennya dibagi menjadi anaphora dan katafora. Anaphora adalah deiksi yang mengacu yang dekat seperti ini, itu, yang terdahulu. Sedangkan katafora deiksis yang mengacu pada apa yang telah disebut seperti berikut, di bawah ini, sebagai berikut. Deiksis sosial mengacu pada kesopanan berbahasa yang menunjukkan ciri sosial penutur dengan mitra tutur atau penulis dengan pembaca sesuai dengan topic yang dibahas. Deiksis social ditunjukkan melalui sistem honorofiks (sopan santun berbahasa atau kesantunan berbahasa) seperti deiksis persona (sampean, panjenengan, piyambakipu)

\section{SARAN}

Berdasarkan hasil temuan penelitian,masih ditemukan banyak kekurangan. Dengan demikian, diharapkan bagi peneliti selanjutnya dapat mengembangkannya dalam pembahasan yang lebih luas. Tidak hanya dalam sebuah wacana cerpen akan tetapi dalam wacana yang lainnya. Jenis-jenis deiksis pada penelitian ini menggunakan lima macam jenis deiksis. Untuk itu, penulis berharap, peneliti selanjutnya dapat mengembangkan lagi jenis deiksis yang ada.

\section{DAFTAR RUJUKAN}

Cahyono, Bambang Yudi. (1995). Aplikasi Teori Skema, Unsur Teks, dan Metakognitif pada Pengajaran Membaca Bahasa Inggris. Malang: Proyek OPF IKIP Malang.

Cruse, Alan. (2000). Meaning in Languages. New York: Oxford University Press. Djajasudarma, Fatimah. (1993). Semantic 1 Pengantar ke Arah Ilmu Makna. Bandung: Eresco.

Fillmore, Charles J. (1971). Toward a Theory of Deixis. PCLLU Papers 3, No. 4:219-242.

Finosa, L. (2004). Komposisi Bahasa Indonesia. Ende Flores: Insan Mulia.

Gee, James Paul. (2005). An Introduction to Discourse. New York: Routledge.

Halliday, M. A. K. dan Ruqaiya Hasan. (1992). Bahasa, Konteks, dan Teks: Aspek-Aspek Bahasa dalam Semiotik Sosial. (Penerjemah Sruddin Barori Tou) Yogyakarta: Gadjah Mada University Press.

Johnstone, Barbara. (2008). Discourse Analysis. UK: Blackwell Publisher Ltd. KBBI. (2002). Jakarta: Departemen Pendidikan dan Kebudayaan. 
Kridalaksana, H. (2008). Kamus Lingustik Edisi Keempat. Jakarta: Gramedia Pustaka Utama.

Keraf, G. (2007). Argumentasi dan Narasi: Komposisi Lanjutan III. Jakarta: Gramedia Pustaka Utama. . (1991). Diksi dan Gaya Bahasa. Jakarta: PT Gramedia Pustaka Utama.

Lyons, John. (1977). Semantic. Cambridge: Cambridge University Press.

Nababan. P.W.J. (1987). Ilmu Pragmatik (Teori dan Penerapannya). Jakarta: Direktorat Jenderal Pendidikan Tinggi.

Nurgiyantoro. Burhan. (1988). Teori Pengkajian Fiksi. Yogyakarta: Gadjah Mada University Press.

Purwo. B. K. (1984). Deiksis dalam Bahasa Indonesia. Jakarta: Balai Pustaka.

Rahardi, Kunjana. (2009). Sosiopragmatik. Jakarta: Erlangga.

Ramlan, M. (2003). Kalimat, Konjungsi dan Preposisi Bahasa Indonesia dalam Penulisan Karangan Ilmiah. Yogyakarta: Universitas Sanata Dharma. .(1987). Ilmu Bahasa Indonesia. Sintaksis. Yogyakarta: CV. Karyono.

Rosidi, Sakban. (2007). "Analisis Wacana Kritis Sebagai Ragam Paradigma Kajian Wacana (Critical Discurse Analysis as Variance of Paradigm Inquiry on Discourse)". Makalah disajikan pada Sekolah Bahasa atas Prakarsa Mahasiswa Islam Komisariat Bahasa Universitas Islam Negeri (UIN) Malang pada tanggal 15 Desember 2007. Malang: Universitas Islam Negeri Malang.

Samsuri. (1987). Analisis Bahasa. Jakarta: Erlangga.

Soeparno. (2002). Dasar-dasar Lingustik Umum. Yogyakarta: PT Tiara Wacana Yogyakarta.

Verhaar, J. W. M. (1998). Asas-asas Linguistik Umum. Yogyakarta: Gadjah Mada Univercity Press.

Widdowson, H.G. (2004). Text, context, pretext. Victoria: Blackwell Publishing.

Wijana, I. D. P. (1998). Dasar-dasar Pragmatik. Yogyakarta: Andi Offset. 